\title{
PROKR2 Gene
}

National Cancer Institute

\section{Source}

National Cancer Institute. PROKR2 Gene. NCI Thesaurus. Code C118609.

This gene is involved in both lig and binding and G protein-coupled receptor signaling. 